\title{
A imbricação entre maxiprocessos e colaboração premiada: o deslocamento do centro informativo para a fase investigatória na Operação Lava Jato ${ }^{1}$
}

\author{
The imbrication between maxiprocesses and cooperation agreement: \\ the displacement of the information center to the preliminary \\ investigation in "Lava Jato Operation"
}

\section{Antonio Eduardo Ramires Santoro ${ }^{2}$}

Universidade Federal do Rio de Janeiro - Rio de Janeiro/RJ, Brasil Universidade Católica de Petrópolis - Petrópolis/RJ, Brasil antoniosantoro@antoniosantoro.com.br

lattes.cnpq.br/9190879263950156

orcid.org/0000-0003-4485-844X

\begin{abstract}
Resumo: A Operação Lava Jato apresenta características maximizadas e a colaboração premiada vem sendo utilizada como principal instrumento na produção de provas. A partir desse contexto, se coloca o seguinte
\end{abstract}

1 Trabalho resultado parcial de projeto de pesquisa financiado pela FAPERJ - Fundação Carlos Chagas Filho de Amparo à Pesquisa do Estado do Rio de Janeiro como bolsista Jovem Cientista do Nosso Estado. Projeto intitulado "Maxiprocessos como instrumentos de Lawfare político: uma análise qualitativa da compatibilidade da "Operação Lava Jato" com um processo penal democrático".

2 Professor Titular de Direito Processual Penal do IBMEC/RJ. Professor Adjunto de Direito Processual Penal e Prática Penal do Programa de Pós-Graduação em Direito da Faculdade Nacional de Direito da Universidade Federal do Rio de Janeiro - FND/UFRJ. Professor Adjunto do Programa de Pós-Graduação em Direito da Universidade Católica de Petrópolis - UCP. Coordenador do Grupo de Pesquisa "O Sistema Penal sob Olhar Crítico" da UFRJ/UCP. Pós-Doutor em Direito Penal e Garantias Constitucionais pela Universidad Nacional de La Matanza - Argentina. Doutor e Mestre em Filosofia pela UFRJ. Mestre em Direito Penal Internacional pela Universidad de Granada - Espanha. Especialista em Direito Penal Econômico pela Universidade de Coimbra - Portugal. Especialista em Direito da Economia pela Fundação Getúlio Vargas. Graduado em Direito pela UERJ. Licenciando em História pela UNIRIO. Advogado criminalista. 
problema: há intrínseca relação entre maxiprocessos e colaboração premiada que deslocou o centro informativo do processo da fase instrutória processual para a investigação preliminar na Operação Lava Jato? A hipótese inicial é que a colaboração premiada é uma característica marcante dos maxiprocessos, sendo que a informação sobre os fatos que forma o convencimento do julgador é produzida durante a fase investigatória. A pesquisa foi realizada pelo método dedutivo, em nível substancialmente exploratório e parcialmente descritivo, a partir de fontes bibliográficas especialmente sobre maxiprocessos e colaboração premiada, bem como pesquisa empírica a partir de fontes documentais de dois grandes processos judiciais que compõem o complexo policial-investigativo/judicial-processual que é a Operação Lava Jato.

PalaVRAS-chaVe: maxiprocessos; colaboração premiada; Operação Lava Jato; centro informativo; investigação.

ABSTRACT: The "Lava Jato Operation" has maximized features and cooperation agreement has been used as the primary instrument in evidence production. From this context, the following problem arises: Is there an intrinsic relationship between maxiprocesses and cooperation agreement that shifts the process information center from the procedural instructional to the preliminary investigation on "Lava Jato Operation"? The initial hypothesis is that cooperation agreement is a hallmark of maxiprocesses, and the factual information that forms the judgment of the judge is produced during the preliminary investigation. The research was conducted by the deductive method, at a substantially exploratory and partially descriptive level, from bibliographic sources especially about maxiprocesses and cooperation agreement, as well as empirical research from documentary sources of two major judicial processes that make up the police-investigative complex / procedural-court which is "Lava Jato Operation".

KeYwords: maxiprocesses; cooperation agreement; "Lava Jato Operation"; information center; investigation.

SUMÁRIO: Introdução; 1. A imbricação entre os maxiprocessos e os meios de obtenção de prova; 2. Operação Lava Jato: a importância da colaboração premiada com contribuição decisiva da imprensa; 3 . A colaboração premiada entre a americanização e a inquisitoriedade; 4. Deslocamento do centro informativo dos maxiprocessos para a fase investigatória; Considerações Finais; Referências. 


\section{INTRODUÇÃO}

A Operação Lava Jato se mostrou um verdadeiro marco de mudança não apenas para o processo penal brasileiro, mas também no cenário político. O fato público e notório de que o juiz por ela responsável, Sérgio Moro, tenha se tornado Ministro da Justiça e da Segurança Pública do atual governo eleito, também agrega razões de política criminal para acreditar que as mudanças no sistema penal não serão restritas à prática policial-judicial da Lava Jato ${ }^{3}$.

Para tanto, basta verificar que o chamado projeto de "Lei Anticrime" - com importantes alterações, é verdade, realizadas durante a tramitação do processo legislativo - converteu-se na Lei no ${ }^{0} 13.964 / 2019$, com a presunçosa epígrafe: "aperfeiçoa a legislação penal e processual penal”, indicativa de uma tentativa de padronizar métodos aplicados de forma peculiar na Operação Lava Jato.

Não se pode ignorar que além da Operação Lava Jato há um grupo considerável de processos penais no Brasil com um novo desenho maximizado, os maxiprocessos, que podem ser inicialmente compreendidos a partir de algumas evidências, tais como, a privilegiada posição social dos investigados (em geral políticos e empresários), a utilização de meios de obtenção de informações tecnologicamente mais avançados e ocultos capazes de devassar a intimidade dos investigados, com a consequente espetacularização do processo, a possibilidade da imprensa expor ao público conversas e vídeos captados em investigações ou mesmo acompanhar em tempo real a execução de fases ostensivas com medidas prisionais, conduções coercitivas ou de buscas e apreensões domiciliares, tornaram o processo conduzido como “operações” um produto de venda essencial à mídia.

3 Essa perspectiva não passou desapercebida por Ricardo Jacobsen Gloeckner que afirmou "Como já seria de se esperar, o novo Ministro da Justiça não poderia deixar passar a oportunidade de novamente, em flagrante servilismo apostólico ao sistema americano, de indicar a tentativa de por via legislativa introduzir, de forma mais ampla, o plea bargain, como fica claro em seu discurso de posse" (GLOECKNER, Ricardo Jacobsen. Um "novo" liberalismo processual penal autoritário? In: GLOECKNER, Ricardo Jacobsen (org.) Plea Bargaining. São Paulo: Tirant lo Blanch, 2019, p. 184). 
Além de esvaziar a ideia de um processo penal fundado nos fatos e inseri-lo em um clima de apreensão folhetinesco, impulsionando o interesse da opinião pública e da mídia, a possibilidade de que a atuação das agências penais seja ditada pela pauta da imprensa, configurando

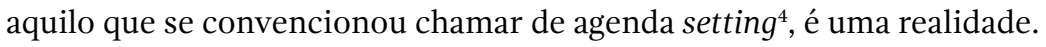

A mais característica das inovações da Operação Lava Jato e dos maxiprocessos é a utilização disseminada da colaboração premiada. Não apenas por ter sido prevista e regulada pela Lei $n^{0} 12.850 / 2013$, poucos meses antes do início da Operação, em 2014, mas sobretudo porque o conteúdo das delações foi o combustível que fez vivo interesse da opinião pública conduzido pelas notícias veiculadas pela mídia.

A forma como os conteúdos das declarações prestadas pelos investigados ou acusados que celebraram acordos de colaboração premiada foram tratados pela mídia, converteu-se em um pré-julgamento público sobre os fatos ainda em fase de investigação preliminar e põe a questão do convencimento ${ }^{5}$ judicial em outras bases.

Afinal, como responder ao problema que se coloca: há intrínseca relação entre maxiprocessos e colaboração premiada que deslocou o centro informativo do processo da fase instrutória processual para a investigação preliminar na Operação Lava Jato?

A hipótese inicial é que a colaboração premiada é uma característica marcante dos maxiprocessos, sendo que a informação sobre os fatos que forma o convencimento do julgador é produzida durante a investigação preliminar.

Para tanto será desenvolvida uma pesquisa pelo método dedutivo, em nível substancialmente exploratório e parcialmente descritivo, a partir de fontes bibliográficas, com o objetivo de identificar as características dos maxiprocessos, comparar categorialmente com a Operação Lava Jato, situar a colaboração premiada entre os sistemas jurídicos da common law e da civil law e enfrentar, finalmente, a questão do momento da produção

4 MCCOMBS, Maxwell. A Teoria da Agenda: a mídia e a opinião pública. Tradução Jacques A. Weinberg. Petrópolis: Vozes, 2009, p. 65 e ss.

5 Importante esclarecer que a distinção entre convicção e convencimento é premissa teórica deste trabalho e prescinde, portanto, de aprofundamento (MARTINS, Rui Cunha. O ponto cego do direito: the Braziliian lessons. $2^{\text {a }}$ ed. Rio de Janeiro: Lumen Juris, 2011, p. 16 a 37). 
da informação que forma o convencimento do magistrado nos maxiprocessos, mais especificamente na Operação Lava Jato.

Será utilizada a pesquisa empírica ${ }^{6}$ a partir de fontes documentais ${ }^{7}$ colhidas pelos pesquisadores vinculados ao Grupo de Pesquisa "Sistema Penal sob Olhar Crítico" composto por docentes e discentes de graduação, mestrado e doutorado da Faculdade Nacional de Direito da Universidade Federal do Rio de Janeiro, coordenados pelo autor do presente artigo.

A pesquisa se iniciou com a identificação dos processos que o Ministério Público Federal apresentava como sendo a primeira e segunda fase da Operação Lava Jato, mas que em geral são de fato os processos iniciados até o segundo semestre de 2017. Foram identificados na primeira instância: 75 (setenta e cinco) processos judiciais com tramitação na $13^{\mathrm{a}}$ Vara Federal de Curitiba, 33 (trinta e três) na $7^{\mathrm{a}}$ Vara

6 Compreende-se por pesquisa empírica aquela que pretende "romper com a tradicional pesquisa teórico-bibliográfica, tão afeita ao Direito" (LINS E HORTA, Ricardo de; ALMEIDA, Vera Ribeiro de; CHILVARQUER, Marcelo. Avaliando o desenvolvimento da pesquisa empírica em direito no Brasil: o caso do projeto Pensando o Direito. Revista de Estudos Empíricos em Direito. São Paulo, vol. 1, n. 2, p. 165, 2014) e se dirige à compreensão de como a normatividade é apropriada socialmente, bem como à busca de resultados analíticos das consequências da interpretação da normatividade (VERONESE, Alexandre. O problema da pesquisa empírica e sua baixa integração na área do Direito: uma perspectiva brasileira da avaliação dos cursos de pósgraduação do Rio de Janeiro. In: Anais do XV Congresso Nacional do CONPEDI, 2015, p. 6019. Disponível em http://www.conpedi.org.br/manaus/arquivos/anais/bh/alexandre_veronese2.pdf).

7 "O levantamento de dados em autos de processos judiciais é uma vertente da técnica 'pesquisa documental'" (SILVA, Paulo Eduardo Alves da. In: MACHADO, Maíra Rocha (org.). Pesquisar Empiricamente o Direito. São Paulo: Rede de Estudos Empíricos em Direito, 2017, p. 277), enquanto para Reginato, a pesquisa documental é uma técnica de pesquisa empírica, a despeito da constante confusão que isso traz nos pesquisadores mais tradicionais (vide REGINATO, Andréa Depieri de A. Uma introdução à pesquisa documental. In: Pesquisar Empiricamente o Direito. Maíra Rocha (org.). Pesquisar Empiricamente o Direito. São Paulo: Rede de Estudos Empíricos em Direito, 2017, p. 193) "Minha intenção é chamar a atenção para o fato de que, cada vez que desenvolvemos uma pesquisa que mobiliza algum tipo de instrumento jurídico, norma, jurisprudência, autos ou peças processuais isoladamente consideradas, estamos no campo da pesquisa empírica em direito, especialmente da pesquisa documental (que, evidentemente, pode e deve se somar a outras diferentes estratégias analíticas de pesquisa).” 
Federal Criminal do Rio de Janeiro e 2 (dois) na $10^{\mathrm{a}}$ Vara Federal do Distrito Federal.

Os processos foram acessados pelos sítios dos tribunais e obtidas as denúncias ou baixadas as denúncias disponíveis no sítio eletrônico do Ministério Público Federal. Foram lidas todas as denúncias para identificar quais faziam menção à existência de colaboradores. Foram identificados 125 (cento e vinte e cinco) colaboradores mencionados nessas 110 (cento e dez) denúncias. Todos os processos, seja na denúncia ou no curso do procedimento, fazem menção a alguma colaboração premiada, portanto não existe processo entre os pesquisados, nesse complexo que se convencionou chamar de Operação Lava Jato, que não utilize de alguma forma o instituto da colaboração premiada.

Todos os autos dos processos que não estavam em segredo de justiça foram acessados para encontrar, além das denúncias, os termos de acordo de Colaboração Premiada e as sentenças, para aqueles processos cuja sentença já havia sido proferida.

Como este trabalho não é o resultado final da pesquisa, mas apenas pretende-se apresentar resultados parciais e o seu objetivo não é proceder a uma análise quantitativa da Operação Lava Jato, mas uma abordagem qualitativa visando identificar se a colaboração premiada deslocou o centro informativo da megaoperação para a fase investigativa, realizar-se-á uma análise de processos. Essa análise não é um estudo de casos, vez que não se pretende generalizar a partir do particular, embora o estudo do caso em si se integre na multiplicidade de estratégias de pesquisa ${ }^{8}$. O que se quer deixar claro é que não se trata de uma pesquisa indutiva.

O objetivo é identificar se o particular apresenta as categorias delineadas pela primeira fase (teórico-bibliográfica) da pesquisa, por meio de uma análise de conteúdo das denúncias, dos termos de acordo de colaboração e, principalmente, das sentenças. Como coloca Silva9, "determinados documentos, pelo seu valor histórico e riqueza de conteúdo,

8 "Um estudo de caso pode ser desenvolvido como estratégia secundária ou complementar em um projeto adotando métodos múltiplos." (MACHADO, Maíra Rocha. O estudo de caso na pesquisa em direito. In: Pesquisar Empiricamente o Direito. Maíra Rocha (org.). Pesquisar Empiricamente o Direito. São Paulo: Rede de Estudos Empíricos em Direito, 2017, p. 358). Op. cit., p. 277. 
demandam investigações em profundidade, que avançam para dados menos evidentes, como o contexto de produção, o perfil e o comportamento dos seus autores...", de tal forma que dados desse tipo "são representados textualmente e, por isso, analisados por técnicas de análise de conteúdo, de discursos e outras do mesmo gênero". Portanto, o objetivo da parte empírica do trabalho de pesquisa aqui exposto é desvelar o que foi dito por trás do expresso, com isso pretende-se identificar o perfil e o comportamento dos autores dos atos analisados.

Para esse objetivo, a análise se realizará sobre os documentos obtidos junto aos autos de dois grandes processos judiciais que compõem o complexo policial-investigativo/judicial-processual que é a Operação Lava Jato, mais especificamente os processos $\mathrm{n}^{0}$ 5025676-71.2014.4.04.7000 e 5026212-82.2014.4.04.7000. A escolha desses específicos processos se deu por quatro motivos específicos: (1) ambos tramitaram perante a $13^{\text {a }}$ Vara Federal de Curitiba e foram julgados por Sérgio Moro, autor de artigo que será analisado entre as fontes bibliográficas especialmente na etapa comparativa entre a Operação Lava Jato e a categoria maxiprocessos; (2) são processos em que os réus Paulo Roberto Costa (em ambos os processos) e Alberto Youssef (no segundo processo) figuraram como colaboradores, o que permite identificar a influência da colaboração premiada; (3) são processos em que já foi proferida sentença, permitindo a análise da colaboração premiada na formação do convencimento judicial; (4) o acesso público é facilitado porque a denúncia, a sentença e a chave de acesso estão na página da web do Ministério Público Federal.

\section{A IMBRICAÇÃo ENTRE OS MAXIPROCESSOS ${ }^{10}$ E OS MEIOS DE OBTENÇÃO DE PROVA}

Ao tratar daquilo que chamou de subsistema penal de exceção, Luigi Ferrajoli identificou que no subsistema penal de exceção o que

10 A apresentação das características dos maxiprocessos é um resultado da pesquisa já apresentado em outras oportunidades total ou parcialmente (vide por todos, em razão de sua exposição mais completa: SANTORO, Antonio Eduardo Ramires e TAVARES, Natália Lucero Frias. Lawfare Brasileiro. $2^{\text {a }}$ edição. Belo Horizonte: D’Plácido, 2019, capítulo 2, p. 49 e ss), porém está 
confere legitimidade à punição não é a razão "jurídica, mas imediatamente política"11.

Nesse contexto, Ferrajoli afirma que a "razão de Estado" se sobrepõe à "razão jurídica" e não existe mais jurisdição, mas "arbítrio policialesco, repressão política"12, incompatível com o Estado de direito. Entre as mais relevantes alterações no modelo clássico de legalidade penal nos processos de emergência ${ }^{13}$ estão o que ele denominou de maxiprocessos ${ }^{14}$.

Assim, com inspiração nas lições de Ferrajoli, é possível traçar as mais importantes características dos maxiprocessos: (1) cobertura midiática massiva; (2) o gigantismo processual ${ }^{15}$; (3) a confusão processual; (4) a mutação substancial do modelo clássico de legalidade penal; (5) o incremento da utilização dos meios investigação ou obtenção de prova.

A primeira característica, denominada (1) "cobertura midiática massiva” dos maxiprocessos, diversamente do que ocorre com o processo penal tradicional, não utiliza o discurso do medo ${ }^{16}$, que termina por apresentar implicações especialmente na segurança pública, mas se vale do discurso da impunidade ${ }^{17}$ e gera três consequências básicas: (i) espe-

exposta aqui de forma resumida como premissa para o desenvolvimento do trabalho cujo resultado inédito se apresenta nesse artigo.

11 FERRAJOLI, Luigi. Direito e razão: teoria do garantismo penal. $4^{\mathrm{a}}$ ed. Tradutores Ana Paula Zomer Sica, Fauzi Hassan Choukr, Juarez Tavares e Luiz Flávio Gomes. São Paulo: Revista dos Tribunais, 2014, p. 747.

12 Idem, p. 751.

13 Op. cit., p. 758 e ss.

14 A expressão maxiprocessos é extraída de FERRAJOLI, Luigi. Op. cit., p. 760 e ss. que o situa em uma espécie de direito penal especial ou de exceção. O termo também pode ser encontrada em ALFONSO, Roberto; CENTONE, Alessandro (a cura di). Fenomenologia del maxiprocesso: venti anni di esperienze. Milão: Giuffreé, 2011. Tratando como "megajustiça” confira-se PRATES, Fernanda. Práticas de interceptação e os riscos do modelo de "megajustiça". In: SANTORO, Antonio Eduardo Ramires; MADURO, Flávio Mirza (org.). Interceptação Telefônica: os 20 anos da Lei nº 9.296/96. Belo Horizonte: D’Plácido, 2016.

Cf. BATISTA, Vera Malaguti. O medo na cidade do Rio de Janeiro. Rio de Janeiro: Revan, 2009. respeito cf. GENELHÚ, Ricardo. Do discurso da impunidade à impunização: o 
taculariza os eventos originados de investigações e processos criminais ${ }^{18}$, (ii) confere publicidade opressiva aos julgamentos criminais interferindo no direito ao um processo justo ${ }^{19} \mathrm{e}$ (iii) determina a agenda dos órgãos atuantes na justiça criminal ${ }^{20}$.

A segunda característica dos maxiprocessos, o (2) "gigantismo processual”, pode ser (i) horizontal (gigantismo processual horizontal), caracterizado pela abertura de "megainvestigações contra centenas de imputados, mediante prisões baseadas em frágeis indícios como primeiros e prejudiciais atos de instrução"21; (ii) vertical (gigantismo processual vertical), que se verifica pela multiplicação de imputações realizadas sobre as mesmas pessoas, com delitos associativos gerando imputações específicas e vice-versa, circularmente; (iii) temporal (gigantismo processual temporal), com processos que se arrastam por anos acompanhados do cumprimento de penas por meio de prisões preventivas ou afastamento de direitos fundamentais ${ }^{22}$ por categorias processuais antes do efetivo julgamento.

A terceira característica, denominada (3) "confusão processual” se apresenta de forma subjetiva (confusão processual subjetiva) e/ou objetiva (confusão processual objetiva).

A confusão processual subjetiva se caracteriza quando a polícia exerce funções tipicamente judiciais ou quando o juiz exerce funções policialescas, tal como a atribuição de tarefas e instrumentos investigativos aos julgadores, como, por exemplo, quando a lei brasileira (art. $1^{\circ}$ da Lei $\left.n^{0} 9.296 / 96\right)$ atribui ao juiz poderes para determinar uma interceptação telefônica de ofício. Tendo em vista a "natural parcialidade da

sistema penal do capitalismo brasileiro e a destruição da democracia. Rio de Janeiro: Revan, 2015.

18 Cf. CASARA, Rubens. Processo Penal do Espetáculo: ensaios sobre o poder penal, a dogmática e o autoritarismo na sociedade brasileira. Curitiba: Emporio do Direito, 2016.

19 Cf. SCHREIBER. Simone. A publicidade opressiva de julgamentos criminais. Rio de Janeiro: Renovar, 2008.

Cf. MCCOMBS. Op. cit..

22 FERRAJOLI, Luigi. Por uma teoria dos direitos e dos bens fundamentais. Tradução Alexandre Salim, Alfredo Copetti Neto, Daniela Cademartori, Hermes Zaneti Júnior, Sérgio Cademartori. Porto Alegre: Livraria do Advogado, 2011, p. 89 e ss. 
polícia em relação à imparcialidade institucional do juiz”23, a confusão subjetiva coloca em xeque um axioma básico do processo penal justo, que é a imparcialidade ${ }^{24}$.

A confusão processual objetiva é característica atribuível aos maxiprocessos. É uma confusão entre processos supostamente diversos ou entre processos e investigações, que terminam por tratar de temas ou fatos parcialmente ou quase integralmente idênticos, gerando novas investigações a partir de processos criminais.

Essa característica da confusão processual objetiva entre investigações e processos implica na potencialização da confusão processual subjetiva, não apenas porque os magistrados exercem funções tipicamente investigativas, mas porque o fazem em um processo para instruir outra(s) investigação(ões) que o terão como julgador em razão da regra da prevenção positiva ${ }^{25}$.

Apontada como mais importante alteração das técnicas punitivas características dos maxiprocessos por Ferrajoli, a característica chamada de (4) "mutação substancial do modelo clássico de legalidade penal" consiste na utilização do 'paradigma do inimigo'26, o que exprime uma personalização do sistema penal. Em outras palavras, um direito penal do réu e não do crime.

A utilização de figuras típicas associativas (como a Organização Criminosa definida pela Lei $\mathrm{n}^{0} 12.850 / 2013$ no Brasil), fórmulas indeterminadas, interpretações elásticas, subjetivas, ideológicas e valorativas, e, por fim, uma predileção por investigar pessoas, ao invés de fatos, identificam essa importante característica dos maxiprocessos ${ }^{27}$.

Em decorrência da mutação substancial do modelo de legalidade penal, com a alteração do paradigma de um processo penal do crime para o

23 FERRAJOLI. Op. cit., p. 762.

24 Esse é um tema que tem direta relação com questão da contaminação do julgador com atos do inquérito, cf. LOPES JR., Aury. Sistemas de Investigação Preliminar no processo penal. $4^{\mathrm{a}}$ edição. Rio de Janeiro: Lumen Juris, 2006, p. 234 e ss.

25 Para uma crítica à prevenção positiva cf. MAYA, André Machado. Imparcialidade e processo penal: da prevenção da competência ao juiz das garantias. $2^{\mathrm{a}} \mathrm{ed}$. São Paulo: Atlas, 2014.

FERRAJOLI. Op. cit., p. 758/759.

27 Idem. 
processo penal do réu, o julgador assume uma posição protagonista, “o juiz torna-se inimigo do réu (...) e não procura a verdade do fato, mas procura no prisioneiro o delito" ${ }^{28}$, permitindo ao magistrado invadir a esfera de privacidade do inimigo, por meio de interceptações e buscas domiciliares.

Essa pessoalização da justiça criminal, que muda o paradigma do crime como centro do sistema para o criminoso, antagonizando-o ao juiz, cria o ambiente para a seletividade política ou ideológica do réu, uma vez que no subsistema penal de exceção a intervenção punitiva se legitima no alcance de objetivos políticos.

Há também, na mutação substancial, uma ontologização do crime como um mal, algo moralizante ou pecaminoso, que de forma coerente procura uma confissão e uma "colaboração mediante denúncia dos coautores" 29 ou mesmo uma confissão à sorrelfa, sem alertas de garantia do direito ao silêncio, como na interceptação telefônica, cujo saldo final é uma pseudo escolha anticriminal, porém confirmatória da hipótese investigatória.

O protagonismo judicial como estratégia para abreviar a confirmação da hipótese investigatória implica com clareza na confusão processual, tanto subjetiva como objetiva, uma vez que o resultado precede o processo e, não raro, é antecipado pela cobertura midiática de forma apriorística à própria investigação, cujos atos ostensivos de delações, interceptações, conduções, buscas e prisões são apenas a face espetacularizada do que já se havia como certo.

Por fim, a última característica consistente no (5) incremento da utilização dos meios de investigação ou obtenção de prova é outro traço distintivo dos maxiprocessos. É uma característica que decorre naturalmente da mutação substancial e da confusão processual, mas guarda especial relação com a cobertura midiática massiva.

Meios de investigação de prova ou meios de obtenção de prova ou meios de pesquisa de prova se caracterizam por (i) serem instrumentos ou atividades extraprocessuais, (ii) que podem ser produzidos na fase investigatória, (iii) sem a participação do investigado e da defesa, (iv) mas com a participação do juiz (v) baseados no fator

\footnotetext{
28 Idem, p. 759.

29 Idem.
} 
surpresa $^{30}$, por isso, não há contraditório direto ${ }^{31}$, (vi) não podem ser repetidos ${ }^{32}$. Diferem dos meios de prova tradicionais que são endoprocessuais, produzidos em juízo, sob o crivo do contraditório direto, com a participação do acusado e sua defesa e, normalmente, podem ser repetidos.

Há, portanto, diante desta quinta característica, uma produção antecipada de informação válida para julgamento antes de serem aplicáveis as garantias processuais ${ }^{33}$, com a participação ativa

30 Chamando-os de métodos ocultos vide PRADO, Geraldo. Prova penal e sistema de controles epistêmicos: a quebra da cadeia de custódia das provas obtidas por métodos ocultos. $1^{\mathrm{a}}$ ed. São Paulo: Marcial Pons, 2014.

31 Uma crítica ao uso do contraditório diferido nas interceptações telefônicas SANTORO, Antonio Eduardo Ramires; RANGEL, Natália. O princípio constitucional do contraditório na interceptação das comunicações telefônicas. In: MENDES, Soraia da Rosa e LONGO, Ana Carolina F. (org.). Segurança Pública. Brasília: IDP, 2015. Duas propostas de estabelecimento do contraditório da interceptação telefônica: CASTRO, Helena Rocha Coutinho de; ABATH, Manuela; ROSENBLATT, Fernanda Fonseca. Por uma investigaçãoo preliminar democrática: o contraditório na interceptação telefônica. In: SANTORO, Antonio Eduardo Ramires; MADURO, Flávio Mirza (org.). Interceptação Telefônica: os 20 anos da Lei no 9.296/96. Belo Horizonte: D’Plácido, 2016 e CÂMARA, Jorge Luis. A inserção da interceptação telefônica em um sistema acusatório coerente com a centralidade do direito de defesa. In: SANTORO, Antonio Eduardo Ramires; MADURO, Flávio Mirza (org.). Interceptação Telefônica: os 20 anos da Lei nº 9.296/96. Belo Horizonte: D’Plácido, 2016.

32 Estamos aqui adotando a distinção realizada por Aury Lopes Jr. entre "repetição", "reprodução” e "ratificação" (LOPES JÚNIOR, Aury. Direito Processual Penal. 15 a ed. São Paulo: Saraiva, 2018, p. 161), de tal sorte que os elementos obtidos com os meios de obtenção de prova só podem ser reproduzidos ou ratificados (e. g., a interceptação telefônica só pode ser reproduzida) e com isso não haverá contraditório direto. O caso específico da colaboração premiada será objeto de análise no contexto desse trabalho.

33 Cumpre esclarecer que não se ignora que de acordo com a disciplina italiana sobre os meios de obtenção de prova, os mesmos não configuram um elemento de prova, todavia está se trabalhando com o conteúdo do art. 155 do Código de Processo Penal brasileiro que em sua parte final estabelece exceções ao contraditório para as provas cautelares, não repetíveis e antecipadas. Com efeito, como coloca Gustavo Badaró, "na prova cautelar, a urgência na obtenção ou no exame do elemento probatório faz com que não se possa instaurar um contraditório contemporâneo a sua produção" e "a urgência costuma estar ligada aos meios de obtenção de prova que, também, necessitam da surpresa para o seu êxito" (BADARÓ, Gustavo. Processo Penal. $4^{\mathrm{a}}$ ed. São Paulo: RT, 2016, p. 424 e 425), razão pela qual o próprio autor afirma que os 
do juiz ${ }^{34}$, aproximando os maxiprocessos de uma lógica tipicamente inquisitiva.

Essa característica apresenta especial importância para desenvolvimento do presente trabalho porque realiza um importante deslocamento do momento informativo central: da instrução processual para a fase de investigação, normalmente aquela em que os meios de obtenção de prova são produzidos.

Acresça-se que a colaboração premiada é um desses meios de obtenção que, como veremos, se mostra essencial nos maxiprocessos.

\section{Operação Lava Jato: a importância da colaboração PREMIADA COM CONTRIBUIÇÃO DECISIVA DA IMPRENSA ${ }^{35}$}

A partir de março de 2014 se iniciou no Brasil, mais especificamente na $13^{\text {a }}$ Vara Federal de Curitiba, Órgão jurisdicional do qual Sérgio Moro figurava como juiz titular, a "Operação Lava Jato", apresentada no sítio eletrônico do Ministério Público Federal como "a maior investigação de corrupção e lavagem de dinheiro que o Brasil já teve"36.

Ainda segundo o Ministério Público Federal, a "Lava Jato" iniciou investigando quatro organizações criminosas lideradas por doleiros e, posteriormente, o Ministério Público Federal recolheu provas de um esquema criminoso envolvendo a Petrobras, o qual duraria pelo menos dez anos e consistiria na organização em cartel de grandes empresas que pagariam propinas a altos executivos e a agentes públicos.

meios de obtenção de prova "são instrumentos para a colheita de fontes ou elementos de prova” (Op. cit., p. 389).

34 Importante ressaltar que nos casos em que o exercício do contraditório será diferido, agravam-se as chances de afetação do posicionamento do julgador em decorrência de sua exposição a informações produzidas unilateralmente e que podem provocar - ainda que inconscientemente - impactos na decisão proferida ao final do processo, impossibilitando a ocorrência daquilo que Rui Cunha Martins aponta como essencial para formação da decisão: suspensão do julgamento imediatista e constrangimento das evidências. Vide MARTINS. Op. cit. SANTORO e TAVARES. Op. cit., p. 57/58. caso/entenda-o-caso. Acesso em: 28 fev. 2020. 
Esse esquema criminoso estaria instaurado na Petrobras em razão da indicação política de três diretorias, que se relacionariam diretamente a três partidos políticos (PP, PT e PMDB) beneficiados por contratos celebrados com as empreiteiras envolvidas.

Hoje a "Lava Jato" não está vinculada apenas à competência da $13^{\mathrm{a}}$ Vara Federal de Curitiba, mas também ao Rio de Janeiro, Distrito Federal e Supremo Tribunal Federal, em razão dos casos que envolvem competência originária.

No ano de 2004, dez anos antes do início da Operação Lava Jato, o mesmo juiz por ela responsável atuante junto à $13^{\mathrm{a}}$ Vara Federal de Curitiba, Sérgio Moro, escreveu um artigo intitulado "Considerações sobre a operação mani pulite" ${ }^{37}$.

Moro descreve com clareza o gigantismo da Operação Mani Pulite como um traço marcante, ao apontar que do início da operação em apenas “dois anos após, 2.993 mandados de prisão haviam sido expedidos; 6.059 pessoas estavam sob investigação, incluindo 872 empresários, 1.978 administradores locais e 438 parlamentares, dos quais quatro haviam sido primeiros-ministros." ${ }^{38}$

A Operação Lava Jato não é diferente. O Ministério Público Federal apresenta números superlativos: são 2.476 procedimentos instaurados, 1.072 mandados de busca e apreensão, 227 mandados de condução coercitiva, 120 mandados de prisão preventiva, 18 mandados de prisão temporária, 6 prisões em flagrante, 548 pedidos de cooperação internacional, 82 acusações criminais contra 347 pessoas e, o mais relevante para o presente trabalho, 176 acordos de colaboração premiada.

Moro apontou como característica da famosa Operação italiana suas razões políticas, pelo que a Mãos Limpas "redesenhou o quadro político na Itália. Partidos que haviam dominado a vida política italiana no pós-guerra (...) foram levados ao colapso..."39.

\footnotetext{
37 MORO, Sergio Fernando. Considerações sobre a operação mani pulite. Revista CEJ, Brasília, v. 8, n. 26, p. 56-62., jul./set. 2004. p. 56-62 
É bem verdade que no trecho parcialmente transcrito ainda não se antevê tenha sido esse resultado político uma finalidade pré-desenhada pelos agentes do sistema jurídico-penal italiano.

Todavia, foi o próprio Moro quem destacou que "Uma nova geração dos assim chamados "giudici ragazzini” (jovens juízes), sem qualquer senso de deferência em relação ao poder político (...), iniciou uma série de investigações sobre a má-conduta administrativa e política." ${ }^{40}$

Há, portanto, uma identificação entre as consequências políticas e a atuação consciente dos magistrados atuantes na Operação Mani Pulite. Resta claro que a Operação Mani Pulite, na exposição de Moro, não contou com juízes inertes e imparciais, vez que em um sistema acusatório julgador algum pode tomar iniciativas investigativas.

A finalidade política da atuação dos magistrados se conforma à confusão processual de que trata Ferrajoli, como uma estratégia para implementar as razões políticas ou de Estado, em contraposição às razões jurídicas que devem nortear um processo de matiz democrático.

Sergio Moro, hoje Ministro da Justiça e da Segurança Pública após redefinição dos rumos políticos do Brasil implementados pela Operação Lava Jato, terminou seu artigo sobre a Operação Mãos Limpas com uma espécie de vaticínio: “No Brasil, encontram-se presentes várias das condições institucionais necessárias para a realização de ação judicial semelhante.” ${ }^{41}$

Moro ainda deixou claro que a atuação dos por ele chamados jovens juízes era conscientemente voltada a atuar como investigadores que pretendem usar de coação para obter confissões e delações:

A estratégia de ação adotada pelos magistrados incentivava os investigados a colaborar com a Justiça: a estratégia de investigação adotada desde o início do inquérito submetia os suspeitos à pressão de tomar decisão quanto a confessar, espalhando suspeita de que outros já teriam confessado e levantando a perspectiva de permanência na prisão pelo menos pelo período da custódia preventiva no caso de manutenção do silêncio, ou, vice-versa, de soltura imediata no caso de uma confissão $(. . .)^{42}$

\footnotetext{
40 Idem. p. 58

41 Idem. p. 61

42 MORO. Op cit. p. 58
} 
É também característico que não se estabeleceu um processo de barganha, em que partes livres negociam uma solução de forma paritária para o problema penal, mas o móvel das atitudes esperadas dos investigados é que ajam sob constante ameaça e com desconhecimento do que sobre eles exista ${ }^{43}$.

O uso de técnicas que subvertem o sistema acusatório e ampliam as incidências autoritárias no âmbito do processo penal para substituir a obrigatória atribuição de ônus probatório à acusação por confissões obtidas a base de ameaças, desconhecimento e medo, bem como delações que impeçam a execução de medidas que antecipam a pena, se tornam tática de atuação ${ }^{44}$.

Uma das táticas para espalhar o receio entre os investigados e obrigá-los a colaborar era o uso da imprensa. Moro afirma que "os responsáveis pela operação mani pulite ainda fizeram largo uso da imprensa” e que esse "constante fluxo de revelações manteve o interesse do público elevado e os líderes partidários na defensiva." ${ }^{45}$

A imprensa, portanto, é um importante instrumento para o uso político do sistema penal, essencial incentivo à colaboração premiada, que ocupa lugar de centralidade nos maxiprocessos, tomados os privilegiados exemplos das Operações Mãos Limpas e Lava Jato. Moro já havia identificado isso com clareza dez anos antes. Não por acaso foram

43 De se observar que a Suprema Corte Norte Americana decidiu no caso Brady vs. Maryland que a acusação apresente as provas da inocência do acusado durante o julgamento. Diante disso vários tribunais passaram a entender que se é exigível que a acusação o faça durante o julgamento, também o será durante o Plea Bargain (PETEGORSKY, Michael Nasser. Plea Bargaining in the dark: the duty to disclosure exculpatory Brady evidence during plea bargain. Fordham Law Review, Nova York, volume 81, n. 6, p. 3599-3650, 2013). Esse é um problema que não se discute no Brasil, nada se trata a respeito do direito da defesa ou investigado de conhecer as provas de inocência de que dispõe a acusação no âmbito da negociação sobre colaboração premiada.

44 Segundo Moro, "por certo, a confissão ou delação premiada torna-se uma boa alternativa para o investigado apenas quando este se encontrar em uma situação difícil. (...) A prisão pré-julgamento é uma forma de se destacar a seriedade do crime e evidenciar a eficácia da ação judicial, especialmente em sistemas judiciais morosos." (Op. cit., p. 59).

Idem. p. 59 
celebrados mais de uma centena de acordos de colaboração no paradigmático maxiprocesso brasileiro.

\section{A COLABORAÇão PREMIADA ENTRE A AMERICANIZAÇÃo E A INQUISITORIEDADE}

Para responder o problema de pesquisa proposto, não basta constatar sob o ponto de vista teórico e pragmático (neste particular com base nos números e na prévia compreensão de Sérgio Moro) que a colaboração premiada é essencial aos maxiprocessos, importa perquirir se o instrumento é compatível com o devido processo, se as informações utilizadas pelo magistrado foram submetidas ao contraditório (mas não a qualquer contraditório, e sim a um contraditório efetivo).

Não se trata de perquirir a natureza jurídica da colaboração premiada, inserida expressamente entre os meios de obtenção de prova no direito brasileiro pela Lei $\mathrm{n}^{0} 12.850 / 2013^{46}$, mas se esse instituto tem condições de respeitar as garantias características de um processo penal democrático.

Igualmente, para além de apenas inseri-la em uma tradição acusatória norte-americana, como tributária do plea bargain, se faz importante compreendê-la como instituto situado no ordenamento brasileiro e como vem sendo manejada.

Jacinto Coutinho e Gabriella Saad Azevedo criticam de forma contundente o que chamam de americanização à brasileira. Começam por expor que para colocar uma névoa na competição do mercado em países onde a corrupção desequilibra as forças que garantiriam a livre iniciativa e o livre mercado, o G7+1 criou o GAFI/FATF (Grupo de Ação Financeira Internacional / Financial Action Task Force) e elencou 40 Recomendações em uma cartilha, com a finalidade de aprimorar leis de combate à corrupção.

46 O que em hipótese alguma implica dizer que essa não pudesse ser uma questão discutida, como se pode verificar, por todos, em VASCONCELLOS, Vinicius Gomes. Colaboração Premiada no processo penal. São Paulo: RT, 2017, especialmente da pág. 53 a 64, mas porque, inobstante o STF tenha definido no julgamento do HC 127.483 que se trata de negócio jurídico processual ao qual se agrega o efeito substancial, tomamos como premissa tratar-se de um meio de obtenção de prova pelas características que esse instituto reúne, conforme foram descritas anteriormente. 
"No caso do processo penal, o movimento foi na direção da adoção, por transplante ${ }^{47}$, do sistema acusatório/adversarial norte-americano (sobretudo), expressão do Common Law"48. O problema, como expõem os autores, é que o Brasil não aderiu ao sistema acusatório, assim, "fezse - é verdadeiro - uma americanização; mas ela é, neste diapasão, uma americanização à brasileira." 49

Ocorre que "o sistema inquisitório brasileiro, potencializado pela americanização à brasileira, sobretudo pela delação premiada (...), agiganta a malvadeza e faz os fins justificarem os meios" ${ }^{50}$.

De acordo com o raciocínio de Coutinho e Azevedo, “...para se importar a delação premiada, seria coerente mudar o sistema processual e, saindo do sistema inquisitório, adotar o sistema acusatório, a fim de que o juiz possa ocupar seu lugar constitucionalmente demarcado." ${ }^{51}$

47 Não se pretende estabelecer aqui a importante discussão de direito comparado sobre os transplantes jurídicos, que comumente têm sua gênese atribuída a Alan Watson (WATSON, Alan. Legal transplants: an approach to Comparative Law. $2^{a}$ ed. Athens: University of Georgia Press, 1993). Essa gênese é, todavia, contestada por John Cairns (CAIRNS, John W. Watson, Walton, and the History of Legal Transplants. Georgia Journal of International and Comparative Law, Athens, n. 3, vol. 41, 2012-2013, p. 640), que atribui a Jeremy Bentham, em sua obra "Time and Place" de 1782 o primeiro emprego dessa metáfora e, ainda antes de Watson, identifica em Frederick Walton no texto "Historical School of Jurisprudence and Transplantation of Law" de 1927 a incorporação da ideia de transplantes. Importante trabalho sobre o tema em língua portuguesa escrito por Deo Campos Dutra aponta que apesar da preocupação de Walton com o empréstimo da legislação, não há uma atenção detida da ao reconhecimento das implicações da compreensão da lei por parte dos sistemas receptores (DUTRA, Deo Campos. Transplantes Jurídicos: história, teoria e crítica no Direito Comparado. Revista da Faculdade de Direito da UFRGS, Porto Alegre, n. 39, p. 76-96, dez. 2018).

COUTINHO, Jacinto Nelson de Miranda e AZEVEDO, Gabriella Saad. A americanização à brasileira do processo penal e a delação premiada (lei n ${ }^{\circ}$ 12.850/13). In: SANTORO, Antonio Eduardo Ramires; MALAN, Diogo; MADURO, Flavio Mirza (org.). Crise no processo penal contemporâneo: escritos em homenagem aos 30 anos da constituição de 1988. Belo Horizonte: D’Plácido, 2018, p. 228.

COUTINHO e AZEVEDO. Op. cit., p. 230.

Idem.

COUTINHO e AZEVEDO. Op. cit., p. 231. 
Todavia, a tese da americanização baseada no que os próprios autores chamaram ora de transplante, ora de importação ${ }^{52}$, não é corroborada de maneira tranquila ${ }^{53}$ pelos teóricos do processo penal ${ }^{54}$. Maximo Langer, em texto seminal, sustenta que "a influência do processo penal americano parece confirmar a versão fraca da tese da americanização e que a versão forte é inaplicável, ou, ao menos, demasiadamente simplista" ${ }^{55}$.

Propondo um novo quadro teórico para conceituar os sistemas adversarial e inquisitorial em que sustenta não se dever compreendê-los apenas a partir da organização e responsabilidades dos atores processuais, "mas também como duas diferentes culturas processuais" ${ }^{56}$, Langer discute

52 Outras expressões como "circulação de modelos jurídicos", "transferência”, "recepção", "transposição", "influência” ou "inspiração", segundo DUTRA (op. cit., p. 81) também são usadas. Ressalte-se que outra compreensão de "transplante" pode ser encontrado em Kahn-Freund, para quem é preciso situar a criação estrangeira no contexto social e político do doador (KAHN-FREUND, Otto. On uses and misuses of Comparative Law. Modern Law Review, Oxford, n. 1, vol. 37, janeiro 1974, p. 27), ao passo que Walton se preocupa mais com o sistema receptor.

53 Damaška (DAMAŠKA, Mirjan. The uncertain fate of evidentiary transplants: anglo-american and continental experiments. The American Journal of Comparative Law, Oxford, vol. 45, p. 851-852, 1997) deixa muito claro que não se pode transplantar um instituto como se estivesse em uma "butique de direito estrangeiro", é necessário verificar se a cultura do destinatário está preparada ou se pode ser preparada, sob pena de se comprar uma imitação ou, como traduziu Renato Stanzioa Vieira, um "pastiche” (VIEIRA, Renato Stanziola. O que vem depois dos "legal transplants"? Uma análise do processo penal brasileiro atual à luz de direito comparado. Revista Brasileira de Direito Processual Penal, Porto Alegre, vol. 4, n. 2, p. 788, mai./set. 2018).

54 Vinícius Vasconcellos aponta como clara a influência do direito estadunidense no mundo todo, mas dá especial importância ao fato de que o fortalecimento da justiça criminal negocial é incentivada inclusive por tratados internacionais (VASCONCELLOS, Vinicius G. As tendências de expansão da Justiça Criminal Negocial em âmbito internacional: a barganha como instituto importado em convergências entre sistemas. Revista de Estudos Criminais, Porto Alegre, v. 19, n. 76, p. 170, jan./mar. 2020).

55 LANGER, Máximo. Dos transplantes jurídicos às traduções jurídicas: a globalização do plea bargaining e a tese da americanização do processo penal. $D E-$ LICTAE: Revista de Estudos Interdisciplinares sobre o Delito, Belo Horizonte, v. 2, n. 3, p. 19-114., 2017, p. 28.

56 Idem. Importa firmar que no Brasil as análises sobre sistemas processuais, embora confiram importância às funções desempenhadas pelos sujeitos processuais, não descuidam de uma análise mais profunda histórica, social, 
os problemas apresentados pela metáfora "transplante legal" e propõe substituí-lo por outra metáfora: "tradução legal".

Langer entende, em linhas muito gerais, que "a prática jurídica transferida - o plea bargaining neste caso - pode ser pensado como um "texto" que foi traduzido de uma "linguagem" - o sistema adversarial estadunidense - para outra "linguagem" - os sistemas inquisitoriais" ${ }^{57}$.

Ao analisar o que entendeu por tradução do plea bargaining alemão, italiano, argentino e francês, Langer compreende que cada um traduziu de maneira diversa e, por isso, "as influências estadunidenses podem acabar produzindo fragmentação e divergência, ao invés da americanização do processo penal na tradição civil law"58.

Ricardo Jacobsen Gloeckner afirma que o plea bargain se encontra “na origem do avanço do 'liberalismo autoritário', tendo como pano de fundo o sistema de justiça penal mais desigual e absurdo do Ocidente: o americano" 59 .

Sem discordar de Langer quanto aos processos de tradução jurídica, Gloeckner afirma que o modelo híbrido de plea bargain "reúne o pior dos dois mundos: a gestão probatória nas mãos dos juízes e os amplos poderes negociais nas mãos dos promotores" e sua adoção "não significa a antítese de um modelo inquisitório" ${ }^{60}$.

Gabriel Ignacio Anitúa sustenta que a importação de mecanismos consensuais do modelo adversarial estadunidense para fins de aceleração da resposta do Estado com a contribuição dos acusados e a eliminação do processo, implementa "um modelo punitivista e típico dos sistemas autoritários” ${ }^{1}$.

cultural e, inclusive, prática (vide, por todos, PRADO, Geraldo. Sistema Acusatório: a conformidade constitucional das leis processuais penais. $3^{\mathrm{a}}$ ed. Rio de Janeiro: Lumen Juris, 2005).

LANGER. Op. cit., p. 30.

Idem.

GLOECKNER. Op. cit., p. 188.

GLOECKNER. Op. cit., p. 187.

ANITUA, Gabriel Ignacio. La importación de mecanismos consensuales del proceso estadounidense, en las reformas procesales latinoamericanas. Revista brasileira de direito processual penal, Porto Alegre, v. 1, 24 p., 2015, p. 43. 
Anitúa sustenta que aqueles que enfatizam o caráter acusatório desses mecanismos de negociação, não o fazem para defendê-los, mas para demonstrarem os problemas que estes modelos apresentam ao projetarem-se nos modelos de tradição histórica continental europeia.

Ainda de forma mais contundente, Anitúa sustenta que "la ecuación secreto más confesión para obtener la verdade, remite a un principio cardinal de los sistemas inquisitivos" ${ }^{62}$. A busca da verdade é um poder exclusivo do soberano no modelo inquisitivo, de tal forma que há uma tendência nos sistemas ibero-americanos a obter confissões e não realizar o juízo público e oral. Os mecanismos de consenso, ao buscarem a confissão, promovem um retorno ao inquisitivo e evitam o contraditório.

Ora, não são poucos os autores que afastam essa ideia de que Plea Bargains sejam confissões, como é o caso de Brandon Garret ${ }^{63}$, todavia suas manifestações nos países de tradição europeia continental não guardam a mesma lógica da estadunidense, em que o acusado pode se declarar culpado ou nolo contendere, de tal forma que uma admissão total ou parcial dos fatos não é a única opção. A admissão do acordo pode decorrer de uma aceitação de quem apenas não quer litigar, sem precisar confessar os fatos ${ }^{64}$.

Alguns autores estadunidenses, de outro lado, como é o caso de Alschuler, admitem o oposto: "the history of plea negotiation, however, is a history of mounting pressure for self-incrimination". ${ }^{65}$ Está muito claro que a afirmação não se faz a partir da regulamentação e tipologia do instituto, mas do fenômeno complexo que se revela na sua prática.

62 ANITÚA. Op. cit., p. 55.

63 Vide GARRET, Brandon L. Por que plea bargains não são confissões? In: GLOECKNER, Ricardo Jacobsen (org.). Plea Bargaining. São Paulo: Tirant lo Balnch, 2019, p. 61.

64 Para uma exposição objetiva, clara a didática dos tipos e modalidades de acordo, que não é o objeto deste trabalho, vide CASTRO, Ana Lara Camargo de. Plea Bargain: Resolução Pactuada nos Estados Unidos. Belo Horizonte: D’Plácido, 2019, p. 84 e ss.

65 "A História da negociação criminal, todavia, é uma história do incremento da pressão pela autoincriminação" (tradução livre) (ALSCHULER, Albert W. Plea Bargaining and Its History. Columbia Law Review, Nova York, v. 79, n. 1, p. 1-43, 1979, p. 40). 
Nesse sentido, é muito perspicaz e pertinente a consideração de Renato Stanziola Vieira ao identificar que o maior problema dos transplantes jurídicos não são os transplantes em si, mas o que vem depois deles. Assim, antes da escolha aleatória de "pedaços de sistemas jurídicos”, é fundamental questionar a "sua funcionalidade na origem" ${ }^{66}$.

Não apenas na origem, mas importa tratar do próprio sistema para o qual o instituto é transplantado. Cynthia Alkon sustenta que nos sistemas de justiça criminal que apresentam problemas de violações de direitos fundamentais os transplantes de institutos negociais são agravantes das suas fragilidades ${ }^{67}$.

Deve se deixar claro, todavia, que a colaboração premiada no direito brasileiro não é um acordo de não persecução penal ${ }^{68}$. A confissão, que é obrigatória ${ }^{69}$, não deverá legalmente afastar o processo e julgamento e implica em uma provável, mas não obrigatória, delação (incriminação de terceiros $)^{70}$. Daí porque a lógica do modelo negocial brasileiro não é - ou não somente ou não era - abreviar o procedimento, mas tem um fundamento probatório claro e para além da confissão.

Por isso é que Augusto Jobim Amaral afirma que “...a palavra dita no 'acordo de delação' é revestida de palavra da verdade ou, no mínimo, aposta como premissa a orientar até mesmo as presunções no processo penal" ${ }^{71}$.

66 VIEIRA. Op. cit. p. 801.

67 ALKON, Cynthia. Plea Bargaining as a Legal Transplant: A Good Idea for Troubled Criminal Justice Systems? Transnational Law and Contemporary Problems, Vermillion, v. 19, p. 359-360, abr./2010.

O acordo de não-persecução penal, por sinal, foi introduzido pela Lei 13.964/2019 com a inclusão do art. 28-A no texto do Código de Processo Penal, e exige a confissão.

69 Em que pese posições contrárias, não há qualquer lógica sistêmica o colaborador não ser parte da organização criminosa (sobre a discussão, vide VASCONCELLOS, Vinicius Gomes. Colaboração Premiada no processo penal. São Paulo: RT, 2017, especialmente da pág.127 a 132).

70 Já que a lei prevê outras possibilidades de resultados a serem buscados por meio da colaboração premiada que não impliquem na incriminação de terceiros.

71 AMARAL, Augusto Jobim. A delação nos sistemas punitivos e seus reflexos no Brasil. In: SANTORO, Antonio Eduardo Ramires; MALAN, Diogo; MADURO, Flavio Mirza (org.). Crise no processo penal contemporâneo: escritos em 
Continua Amaral analisando que a "delação acaba por se tornar atualmente o eixo sobre o qual gira um novo regime de verdade no processo penal brasileiro. A sua importância é evidenciada, portanto, pela tamanha submissão a qual tanto a investigação quanto a sentença devem a ela obedecer"72.

Para além da identificação do novo regime de verdade no processo penal brasileiro que realizou Amaral, dado que a expressão novo se refere aos processos aos quais a colaboração premiada ocupa posição essencial, o autor de forma perspicaz aponta que há uma submissão da investigação e da sentença a ela. Não parece acaso ter excluído a fase processual de instrução.

\section{Deslocamento do CEntro informativo dos maxiprocessos PARA A FASE INVESTIGATÓRIA}

A colaboração premiada encerra dois problemas imbricados, porém distintos quanto ao momento da produção de informação que constituirá o centro de referência para convencimento do julgador.

Um diz respeito às declarações do colaborador, outro à regra de corroboração. Dito de outra forma, uma coisa é o que o colaborador diz, outra é o que ele prova.

Não há qualquer dificuldade em admitir-se que a transferência do ônus probatório do órgão de acusação para o colaborador é uma premissa básica do instituto, muito embora isso não esteja dito com essas palavras, mas ao exigir que o colaborador apresente provas de corroboração ${ }^{73}$ do que declarou, outra não pode ser a conclusão.

Essa questão do deslocamento do ônus probatório, embora represente uma violação de um axioma básico do devido processo, não é o objeto deste trabalho. O centro informativo da persecução, o momento em que a produção de dados a serem valorados pelo julgador é determinante constitui o efetivo objetivo.

homenagem aos 30 anos da constituição de 1988. Belo Horizonte: D’Plácido, 2018, p. 81.

72 AMARAL. Op. cit. p. 81

73 Essa exigência é agora expressa na Lei $12.850 / 2013$ no seu $\S 4^{\circ}$ do art. $3^{\circ}$-C, incluído pela Lei 13.964/2019. 
Quanto às declarações do colaborador, como bem observa Vasconcellos, a efetiva colaboração se faz depois de formalizado e homologado o acordo, e "como regra, tais atos preliminarmente têm ocorrido em momento anterior ao início formal do processo (recebimento da denúncia) de modo que os relatos iniciais apresentados pelo potencial colaborador são obtidos em sigilo, durante as investigações"74.

Não há dúvida de que a lei estabelece uma limitação à utilização das declarações do colaborador como fundamento exclusivo da sentença condenatória. Isso, todavia, não pode ser confundido com limitação valorativa. Em outras palavras, não é possível limitar a valoração que é feita pelo juízo por meio de regras legais, porque é um ato não passível, via de regra, de controle externo legal.

A valoração das informações, enquanto etapa de um processo decisório que se funda em um método epistêmico do conhecimento a respeito dos fatos em julgamento, não pode ser confundida com o estágio posterior que é a justificação e que se presta a possibilitar o controle a posteriori ${ }^{75}$.

74 VASCONCELLOS. Op. cit., p. 192.

75 Como já dito na nota 5 , aderimos aqui à compreensão de Rui Cunha Martins de que há um "trajeto epistêmico" no processo decisório, "operando em sucessivas etapas, cada uma delas correspondendo a um estádio epistêmico que, partindo da crença e passando pela dúvida, alcançaria sucessivamente o assentimento, a confiança, a aceitação e a própria convicção, para depois se prolongar na decisão e, por fim, na justificação, ambas situadas, nesta perspectiva, nos antípodas da crença originária, convirá contrapor a imagem de um circuito em que cada um desses estádios se disponibiliza a interagir e a contaminar os restantes - curto-circuitando, justamente, a demarcação ideal entre eles. Um mecanismo em que, significativamente, se torna possível, por exemplo, encontrar lado a lado, e não já no polo oposto, aquelas que são classicamente tidas como a primeira e última etapas, crença e justificação, as quais podem apresentar vizinhanças inesperadas e com fortíssimo potencial de absorção (é de resto sabido que a obrigatoriedade de justificação da decisão e o exercício da motivação, teoricamente entendidos como controle a posteriori, funcionam de fato como constrangimento por antecipação)" (MARTINS. Op. cit., p. 16). No mesmo sentido é o entendimento de Perfecto Andrés Ibañez para quem a motivação tem "caráter de justificação", que "opera como racionalização posterior", e "não como individualização do iter lógico-jurídico mediante o qual o juiz chegou à decisão" ou "atividade do tipo prevalentemente descritiva”. (ANDRÉS IBÁÑEZ, Perfecto. Valoração da prova e sentença penal. Tradução Ledio Rosa de Andrade, Carmem Freitas e Wilson Demo. Rio de Janeiro, Lumen Juris, 2006. p. 67). 
Ora, é o próprio artigo 155 do Código de Processo Penal que vincula a formação da convicção à prova produzida em contraditório, para depois abrir, pela inserção do advérbio "exclusivamente", a oportunidade de superar a vinculação com dados não submetidos ao contraditório. É o que Martins chamou de "operador de contágio"76. O convencimento está, assim, liberto das amarras (que é precisamente o contraditório) impostas à convicção e, pior, do controle posterior.

É bem verdade que o $\$ 16$ do art. $4^{\mathrm{o}}$ da Lei $\mathrm{n}^{\mathrm{o}} 12.850 / 2013^{77}$ era necessário, já que sendo um meio de obtenção de prova com previsão de rito cautelar, poder-se-ia inseri-lo nas ressalvas finais do art. 155 supracitado.

Não é suficiente, entretanto, para evitar o contágio do convencimento.

Ao analisar os processos $\mathrm{n}^{\circ}$ 5025676-71.2014.4.04.7000 e 5026212-82.2014.4.04.7000 da Operação Lava Jato, procurou-se identificar o que está dito, apesar de não expresso em palavras, para identificar a "operação de contágio"78.

Em importante trecho da sentença proferida no processo $\mathrm{n}^{\circ}$ 5025676-71.2014.4.04.7000, o julgador afastou a alegação de inocência realizada em juízo por uma das rés por estar em contradição com sua confissão em sede de acordo de colaboração premiada.

De forma clara, o juiz afirmou que "a alegação de inocência de Shanni Azevedo Costa Bachmann em Juízo não é muito consistente com o fato dela mesmo ter celebrado acordo de colaboração premiada com o Ministério Público Federal, assumindo a responsabilidade pelos crimes", desvelando que o único o fundamento (no sentido de justificação) da "não consistência" da alegação de inocência é exatamente o fato dela ter assumido responsabilidade pelos crimes em sua colaboração premiada.

76 MARTINS. Op. cit., p. 19 e ss.

77 Agora modificado pela Lei $\mathrm{n}^{\circ} 13.964 / 2019$, o referido parágrafo proíbe não apenas que a sentença condenatória seja proferida com base apenas nas declarações do colaborador, mas também as medidas cautelares e o recebimento da inicial acusatória.

78 Expressão usada a partir da já falada expressão "operadores de contágio" de MARTINS. Op. cit., p. 19 e ss. 
Tal justificativa está a demonstrar não apenas que na formação do convencimento a crença não foi constrangida pela prova produzida em contraditório, mas também que a confissão ocupa lugar central na lógica inquisitiva autoritária em que se insere esse mecanismo de barganha traduzido ${ }^{79}$ para o sistema brasileiro.

Ao aplicar a pena à ré, o juiz justificou a redução de um terço da pena afirmando que "não cabe redução maior considerando que, em Juízo, o depoimento da condenada não foi totalmente consistente".

Verifica-se não apenas que não houve constrangimento quanto à formação do convencimento, como aplicou-se a menor diminuição possível, como uma espécie de benefício-sanção pela imposição de uma dificuldade na solução conforme sua crença fundada em evidências.

Mesmo soluções que vêm sendo discutidas para permitir o exercício de defesa e, especialmente o contraditório, como é o caso do duplo registro $^{80}$, que terminaria por permitir um contraditório diferido, diante da justificativa sentencial, não teria rendimento para afastar a crença.

Ainda mais importante para confirmar isso é o trecho em que o julgador termina por corroborar o que foi afirmado por Amaral, o que já foi dito, mas importa ser repetido: a delação é "premissa a orientar até mesmo as presunções no processo penal”. Acresça-se: a principal presunção é a de culpa.

O juiz, ao analisar a concessão dos benefícios a Paulo Roberto Costa, pai da ré que celebrou acordo de colaboração, mas em juízo alegou inocência, entendeu que "não se justifica negar os benefícios quando há alterações meramente circunstanciais dos depoimentos auto-incriminatórios e que não prejudicam a condenação deles ou de terceiros".

Não é difícil verificar que o critério definidor da concessão do benefício, segundo a justificativa expressa, não teve nenhuma relação com os elementos de corroboração ou com critérios de verdade, mas não ter prejudicado “a condenação deles ou de terceiros”, de tal forma que o móvel

79 Para usar a expressão de Langer. Op. cit., p. 63 e ss.

80 BORRI, Luiz A.; SOARES, Rafael J. A obrigatoriedade do duplo registro da colaboração premiada e o acesso pela defesa técnica. Revista Brasileira de Direito Processual Penal, Porto Alegre, vol. 3, n. 1, p. 167-187, jan./abr. 2017. p. 177-178. 
da decisão é precisamente a presunção de culpa que precisa ser convertida em condenação e não pode ser prejudicada pelos dados dissonantes.

Importa invadir o segundo problema: a prova de corroboração.

Como já colocado, trata-se de uma transferência do ônus da prova, vez que é o colaborador que passa a ter que produzir prova para demonstrar o que declarou e, assim, ser beneficiado pelo que foi acordado.

Em tese é preciso que essas provas de corroboração, para serem consideradas provas, sejam "produzidos durante a fase processual, com respeito ao contraditório" ${ }^{81}$. Aduza-se que a concessão do benefício pactuado depende de que o juiz verifique a efetiva existência das provas de corroboração, devendo-se exigir que o julgador fundamente adequadamente.

Nos processos analisados, o juiz julgador utilizou um texto pronto, repetindo basicamente as mesmas palavras. Veja-se trecho extraído da sentença do processo $\mathrm{n}^{\circ}$ 5026212-82.2014.4.04.7000:

A efetividade da colaboração de Paulo Roberto Costa não se discute. Prestou informações e forneceu provas relevantíssimas para Justiça criminal de um grande esquema criminoso. Embora parte significativa de suas declarações demande ainda corroboração, já houve confirmação pelo menos parcial do declarado.

É um trecho que apresenta uma justificativa bastante autoritária, vez que parte da premissa que algo em um processo penal "não se discute”, como se fosse possível em um modelo democrático de processo não discutir alguma coisa, especialmente prova, já que a efetividade da colaboração depende da existência e pertinência das provas de corroboração.

Ao inviabilizar a discussão, parece que o contraditório sobre as provas de corroboração fica igualmente inviabilizado.

Todavia, deve se reconhecer que este processo traz um dado peculiar. É que, de acordo com a fundamentação sentencial, os acordos celebrados por Paulo Roberto Costa e Alberto Youssef não teriam se prestado a apresentar provas de corroboração dos fatos em julgamento, mas de outros fatos.

81 VASCONCELLOS. Op. cit., p. 218. 
É o que se extrai do seguinte trecho, em que o julgador refuta a alegação das demais defesas no sentido de que a prova dos autos se baseia exclusivamente em acordos de colaboração premiada: "Os acordos de colaboração firmados com Paulo Roberto Costa e Alberto Youssef visaram principalmente permitir a descoberta de novos fatos delitivos, mas, para a presente ação penal, eram desnecessários”.

E para refutar a tese defensiva e, bem assim, a desnecessidade dos acordos de colaboração e suas consequentes confissões, asseverou o juiz que "mesmo antes das confissões, a prova já era categórica, tanto que levou à prisão cautelar dos principais envolvidos, Paulo Roberto Costa e Alberto Youssef".

Não é demais frisar que o magistrado usou as expressões "Os acordos de colaboração firmados (...) eram desnecessários" e "mesmo antes das confissões, a prova já era categórica”, deixando registrado que seu convencimento já estaria formado antes da colaboração e da confissão.

Para confirmar tal assertiva, o julgador estabeleceu uma relação de causa e efeito entre a existência de prova "categórica" e a "prisão cautelar dos principais envolvidos, Paulo Roberto Costa e Alberto Youssef”, o que implica dizer que sua crença na culpa estava formada desde o momento em que decretou as referidas prisões.

Embora se possa simplesmente afirmar que as prisões foram decretadas com base nos elementos informativos da investigação porque o acesso ao processo permite fazê-lo, é possível extrair do próprio relatório da sentença o seguinte trecho: "Ainda na fase de investigação, foi decretada, a pedido da autoridade policial e do Ministério Público Federal, a prisão preventiva dos acusados Alberto Youssef e Paulo Roberto Costa".

Se a prisão preventiva foi decretada "ainda na fase de investigação” e se antes das confissões "a prova já era categórica, tanto que levou à prisão cautelar" e, mais do que isso, se as próprias colaborações "para a presente ação penal, eram desnecessárias”, é porque o magistrado não poderia ter sua crença constrangida pela prova.

A decisão estava tomada, desde o momento da decretação da prisão cautelar, com base nos elementos informativos da investigação preliminar.

Naturalmente não se pretende com essa análise de dois processos da Operação Lava Jato afirmar que houve uma demonstração empírica de que há um deslocamento do centro informativo em todo e qualquer 
processo penal no Brasil, mas o que a pesquisa bibliográfica demonstrou e não foi refutado pelos dados coletados dos processos analisados, é que na Operação Lava Jato o centro informativo está na investigação preliminar.

\section{Considerações finais}

Ao final da presente pesquisa é possível responder, com os dados bibliográficos e empíricos coletados e analisados, ao problema inicialmente proposto com a confirmação da hipótese.

São características dos maxiprocessos: 1) cobertura midiática massiva; (2) o gigantismo processual ${ }^{82}$; (3) a confusão processual; (4) a mutação substancial do modelo clássico de legalidade penal; (5) o incremento da utilização dos meios de investigação ou obtenção de prova.

O então juiz responsável pela Operação Lava Jato já apresentava, em artigo publicado dez anos antes do seu início, as características da Operação Mãos Limpas, que configurou um importante e paradigmático maxiprocesso italiano, estabelecendo as mesmas condições para que similar medida fosse tomada no Brasil.

A colaboração premiada foi apresentada como instrumento essencial para o sucesso de tal estratégia, desde que fosse utilizada com a decisiva participação e apoio da mídia.

Não se pode descuidar do fato de que a tradição jurídica inquisitória revela um desamor pelo contraditório. Todavia, o traço marcadamente acusatório definido pela Constituição de 1988, associado às adesões e ratificações dos tratados internacionais sobre direitos humanos definem a necessidade de alteração substancial das normas ordinárias processuais penais.

O desenho processual definido pela Operação Lava Jato, enquanto um maxiprocesso, se distancia do traço democrático estabelecido constitucionalmente para o processo penal brasileiro. A colaboração premiada tem fundamental importância neste contexto, especialmente quanto à epistemologia da prova.

82 Expressão cunhada por FERRAJOLI. Op. cit., p. 760. 
A colaboração premiada enquanto medida negocial inspirada no plea bargain estadunidense ao ser traduzida para ordenamento de matiz inquisitória, não torna o sistema processual penal acusatório e reproduz as permanências autoritárias, especialmente a confissão, agora enquanto delação, como novo critério central de produção da verdade.

A colaboração premiada afeta diretamente dois axiomas do processo penal democrático: a presunção de inocência, ao transferir o ônus da prova para o colaborador, e o contraditório, ao deslocar o momento de formação do convencimento para a fase de investigação.

Muito embora a prova, entendida tão somente como aquela produzida sob o crivo do contraditório, devesse formar a convicção judicial, são os dados da investigação nos maxiprocessos que terminam por formar o convencimento do julgador, em especial a colaboração premiada, seja pelas declarações do colaborador, seja pelas provas de corroboração, deslocando o centro informativo para a fase de investigação preliminar.

Não é difícil entender por que há um claro inconformismo do Ministro da Justiça Sérgio Moro $^{83}$ com um dos poucos pontos em que o processo legislativo que resultou na criação da Lei $n^{0}$ 13.964/2019 foi alterado para acrescentar um novo instituto não previsto no projeto original, que é o juiz das garantias.

Mais do que afastar o juiz que tomou decisões durante a investigação, de acordo com novo texto do art. $3^{\circ}-\mathrm{C}$, em seu $\S 3^{\circ}$, os autos que compõem as matérias de competência do juiz das garantias ficarão acautelados à disposição das partes, mas não serão apensados aos autos e, portanto, não será dado acesso ao juiz da instrução e julgamento.

Essa medida se mostra, na reforma da investigação preliminar, aquela que poderá, se respeitada, impedir ou dificultar esse deslocamento do centro informativo, conferindo relevância ao contraditório, ao contrário do desenho processual próprio da Operação Lava Jato e dos maxiprocessos.

83 Vide por todos <https://www.conjur.com.br/2019-dez-28/ferias-moro-segue-cruzada-redes-juiz-garantias>. Acessado em: 15 jan. 2020. 


\section{REFERÊNCIAS}

ALSCHULER, Albert W. Plea Bargaining and Its History. Columbia Law Review, Nova York, v. 79, n. 1, p. 1-43, 1979.

ALFONSO, Roberto; CENTONE, Alessandro (a cura di). Fenomenologia del maxiprocesso: venti anni di esperienze. Milão: Giuffreé, 2011.

ALKON, Cynthia. Plea Bargaining as a Legal Transplant: A Good Idea for Troubled Criminal Justice Systems? Transnational Law and Contemporary Problems, Vermillion, v. 19, p. 355-418, abr./2010.

AMARAL, Augusto Jobim. A delação nos sistemas punitivos e seus reflexos no Brasil. In: SANTORO, Antonio Eduardo Ramires; MALAN, Diogo; MADURO, Flavio Mirza (org.). Crise no processo penal contemporâneo: escritos em homenagem aos 30 anos da constituição de 1988. Belo Horizonte: D’Plácido, 2018.

ANDRÉS IBÁÑEZ, Perfecto. Valoração da prova e sentença penal. Tradução Ledio Rosa de Andrade, Carmem Freitas e Wilson Demo. Rio de Janeiro, Lumen Juris, 2006.

ANITUA, Gabriel Ignacio. La importación de mecanismos consensuales del proceso estadounidense, en las reformas procesales latinoamericanas. Revista brasileira de direito processual penal, Porto Alegre, v. 1, 24 p., 2015.

BADARÓ, Gustavo. Processo Penal. 4a ed. São Paulo: RT, 2016.

BATISTA, Vera Malaguti. O medo na cidade do Rio de Janeiro. Rio de Janeiro: Revan, 2009.

BORRI, Luiz A.; SOARES, Rafael J. A obrigatoriedade do duplo registro da colaboração premiada e o acesso pela defesa técnica. Revista Brasileira de Direito Processual Penal, Porto Alegre, vol. 3, n. 1, p. 167-187, jan./abr. 2017.

CAIRNS, John W. Watson, Walton, and the History of Legal Transplants. Georgia Journal of International and Comparative Law, Athens, n. 3, vol. 41, 2012-2013, p. 637-686

CASARA, Rubens. Processo Penal do Espetáculo: ensaios sobre o poder penal, a dogmática e o autoritarismo na sociedade brasileira. Curitiba: Emporio do Direito, 2016.

CÂMARA, Jorge Luis. A inserção da interceptação telefônica em um sistema acusatório coerente com a centralidade do direito de defesa. In: SANTORO, Antonio Eduardo Ramires; MADURO, Flávio Mirza (org.). Interceptação Telefônica: os 20 anos da Lei n 9.296/96. Belo Horizonte: D’Plácido, 2016. 
CASTRO, Ana Lara Camargo de. Plea Bargain: Resolução Pactuada nos Estados Unidos. Belo Horizonte: D’Plácido, 2019.

CASTRO, Helena Rocha Coutinho de; ABATH, Manuela; ROSENBLATT, Fernanda Fonseca. Por uma investigação preliminar democrática: o contraditório na interceptação telefônica. In: SANTORO, Antonio Eduardo Ramires; MADURO, Flávio Mirza (org.). Interceptação Telefônica: os 20 anos da Lei n 9.296/96. Belo Horizonte: D’Plácido, 2016.

COUTINHO, Jacinto Nelson de Miranda e AZEVEDO, Gabriella Saad. A americanização à brasileira do processo penal e a delação premiada (lei no 12.850/13). In: SANTORO, Antonio Eduardo Ramires; MALAN, Diogo; MADURO, Flavio Mirza (org.). CRISE no processo penal contemporâneo: escritos em homenagem aos 30 anos da constituição de 1988. Belo Horizonte: D’Plácido, 2018.

DAMAŠKA, Mirjan. The uncertain fate of evidentiary transplants: anglo-american and continental experiments. The American Journal of Comparative Law, Oxford, vol. 45, p. 839-852, 1997.

DUTRA, Deo Campos. Transplantes Jurídicos: história, teoria e crítica no Direito Comparado. Revista da Faculdade de Direito da UFRGS, Porto Alegre, n. 39, p. 76-96, dez. 2018.

FEELEY, Malcolm M. Plea Bargaining e a estrutura do processo criminal. In: GLOECKNER, Ricardoo Jacobsen (org.). Plea Bargaining. São Paulo: Tirant lo Balnch, 2019.

FERRAJOLI, Luigi. Direito e razão: teoria do garantismo penal. $4^{\mathrm{a}}$ ed. Tradutores Ana Paula Zomer Sica, Fauzi Hassan Choukr, Juarez Tavares e Luiz Flávio Gomes. São Paulo: Revista dos Tribunais, 2014.

FERRAJOLI, Luigi. Por uma teoria dos direitos e dos bens fundamentais. Tradução Alexandre Salim, Alfredo Copetti Neto, Daniela Cademartori, Hermes Zaneti Júnior, Sérgio Cademartori. Porto Alegre: Livraria do Advogado, 2011.

GARRET, Brandon L. Por que plea bargains não são confissões? In: Plea Bargaining. Organizado por Ricardo Jacobsen Gloeckner. São Paulo: Tirant lo Balnch, 2019.

GENELHÚ, Ricardo. Do discurso da impunidade à impunização: o sistema penal do capitalism brasileiro e a destruição da democracia. Rio de Janeiro: Revan, 2015.

GLOECKNER, Ricardo Jacobsen. Um “novo” liberalismo processual penal autoritário? In: GLOECKNER, Ricardoo Jacobsen (org.). Plea Bargaining. São Paulo: Tirant lo Balnch, 2019. 
KAHN-FREUND, Otto. On uses and misuses of comparative law. The Modern Law Review, Oxford, v. 37, n. 1, p. 1-27, jan. 1974. http://dx.doi.org/10.1111/j.1468-2230.1974.tb02366.x

LANGER, Máximo. Dos transplantes jurídicos às traduções jurídicas: a globalização do plea bargaining e a tese da americanização do processo penal. DELICTAE: Revista de Estudos Interdisciplinares sobre o Delito, Belo Horizonte, v. 2, n. 3, p. 19-114., 2017.

LINS E HORTA, Ricardo de; ALMEIDA, Vera Ribeiro de; CHILVARQUER, Marcelo. Avaliando o desenvolvimento da pesquisa empírica em direito no Brasil: o caso do projeto Pensando o Direito. Revista de Estudos Empíricos em Direito, São Paulo, vol. 1, n. 2, p. 162-183, 2014.

LOPES JR., Aury. Sistemas de Investigação Preliminar no processo penal. $4^{\mathrm{a}}$ edição. Rio de Janeiro: Lumen Juris, 2006.

LOPES JÚNIOR, Aury. Direito Processual Penal. 15ª ed. São Paulo: Saraiva, 2018.

MACHADO, Maíra Rocha. O estudo de caso na pesquisa em direito. In: MACHADO, Maíra Rocha (org.). Pesquisar Empiricamente o Direito. São Paulo: Rede de Estudos Empíricos em Direito, 2017.

MARTINS, Rui Cunha. O ponto cego do direito: the brazilian lessons. $3^{\mathrm{a}}$ edição. São Paulo: Atlas, 2013.

MAYA, André Machado. Imparcialidade e processo penal: da prevenção da competência ao juiz das garantias. $2^{\mathrm{a}}$ ed. São Paulo: Atlas, 2014.

MCCOMBS, Maxwell. A Teoria da Agenda: a mídia e a opinião pública. Tradução Jacques A. Weinberg. Petrópolis: Vozes, 2009.

MORO, Sergio Fernando. Considerações sobre a operação mani pulite. Revista CEJ, Brasília, v. 8, n. 26, p. 56-62., jul./set. 2004.

PETEGORSKY, Michael Nasser. Plea Bargaining in the dak: the duty to disclosure exculpatory Brady evidence during plea bargain. Fordham Law Review, Nova York, volume 81, n. 6, p. 3599-3650, 2013.

PRATES, Fernanda. Práticas de interceptação e os riscos do modelo de "megajustiça”. In: SANTORO, Antonio Eduardo Ramires; MADURO, Flávio Mirza (org.). Interceptação Telefônica: os 20 anos da Lei n 9.296/96. Belo Horizonte: D’Plácido, 2016.

PRADO, Geraldo. Prova penal e sistema de controles epistêmicos: a quebra da cadeia de custódia das provas obtidas por métodos ocultos. 1a ed. São Paulo: Marcial Pons, 2014. 
PRADO, Geraldo. Sistema Acusatório: a conformidade constitucional das leis processuais penais. 3a ed. Rio de Janeiro: Lumen Juris, 2005.

REGINATO, Andréa Depieri de A. Uma introdução à pesquisa documental. In: MACHADO, Maíra Rocha (org.). Pesquisar Empiricamente o Direito. São Paulo: Rede de Estudos Empíricos em Direito, 2017.

SACCO, Rodolfo. An approach to Comparative Law (Installment I of II). American Journal of Comparative Law, Oxford, n. 3, vol. 39, p. 1-34.

SANTORO, Antonio Eduardo Ramires e TAVARES, Natália Lucero Frias. Lawfare Brasileiro. 2a edição. Belo Horizonte: D’Plácido, 2019.

SANTORO, Antonio Eduardo Ramires; RANGEL, Natália. O princípio constitucional do contraditório na interceptação das comunicações telefônicas. In: MENDES, Soraia da Rosa e LONGO, Ana Carolina F. (org.). Segurança Pública. Brasília: IDP, 2015.

SCHREIBER. Simone. A publicidade opressiva de julgamentos criminais. Rio de Janeiro: Renovar, 2008.

SILVA, Paulo Eduardo Alves da. In: MACHADO, Maíra Rocha (org.). Pesquisar Empiricamente o Direito. São Paulo: Rede de Estudos Empíricos em Direito, 2017.

TEUBNER, Gunther. Legal Irritants: Good Faith in British Law or how unifying Law ends up new divergences. Modern Law Review, Oxford, vol. 61, 1998, p. 11-32.

VASCONCELLOS, Vinicius Gomes. Colaboração Premiada no processo penal. São Paulo: RT, 2017.

VASCONCELLOS, Vinicius G. As tendências de expansão da Justiça Criminal Negocial em âmbito internacional: a barganha como instituto importado em convergências entre sistemas. Revista de Estudos Criminais, v. 19, n. 76, p. 153173, jan./mar. 2020.

VERONESE, Alexandre. O problema da pesquisa empírica e sua baixa integração na área do Direito: uma perspectiva brasileira da avaliação dos cursos de pósgraduação do Rio de Janeiro. In: Anais do XV Congresso Nacional do CONPEDI, 2015. Disponível em http://www.conpedi.org.br/manaus/arquivos/anais/bh/ alexandre_veronese2.pdf. Acesso em: 28 fev. 2020

VIEIRA, Renato Stanziola. O que vem depois dos "legal transplants”? Uma análise do processo penal brasileiro atual à luz de direito comparado. Revista Brasileira de Direito Processual Penal, Porto Alegre, vol. 4, n. 2, p. 767-806, mai./set. 2018. https://doi.org/10.22197/rbdpp.v4i2.133

WATSON, Alan. Legal transplants: an approach to Comparative Law. $2^{\text {a }}$ ed. Georgia: University of Georgia Press, 1993. 


\section{Informações adicionais e declarações dos autores (integridade científica)}

Agradecimentos (acknowledgement): Agradeço à FAPERJ - Fundação Carlos Chagas Filho de Amparo à Pesquisa do Estado do Rio de Janeiro pelo financiamento que vem sendo feito a esse projeto de pesquisa pela bolsa Jovem Cientista do Nosso Estado. Agradeço também a todas as pesquisadoras e pesquisadores do Grupo de Pesquisa "O Sistema Penal sob Olhar Crítico", especialmente Olga Martins, Stefanie Araújo, Matheus Modesto, Lorena Ribeiro, Rodrigo Saraiva, Natália Lucero e Carolina Cyrillo, que no último ano de pesquisa contribuíram de maneira fundamental para a coleta e análise dos dados da pesquisa.

Declaração de conflito de interesses (conflict of interest declaration): o autor confirma que não há conflitos de interesse na realização das pesquisas expostas e na redação deste artigo.

Declaração de autoria e especificação das contribuições (declaration of authorship): todas e somente as pessoas que atendem os requisitos de autoria deste artigo estão listadas como autores; todos os coautores se responsabilizam integralmente por este trabalho em sua totalidade.

Declaração de ineditismo e originalidade (declaration of originality): o autor assegura que o texto aqui publicado não foi divulgado anteriormente em outro meio e que futura republicação somente se realizará com a indicação expressa da referência desta publicação original; também atesta que não há plágio de terceiros ou autoplágio. 
Dados do processo editorial

(http://www.ibraspp.com.br/revista/index.php/RBDPP/about/editorialPolicies)

- Recebido em: 15/01/2020

Equipe editorial envolvida

- Controle preliminar e verificação de plágio: 19/01/2020

- Avaliação 1: 23/01/2020

- Editor-chefe: 1 (VGV)

- Avaliação 2: 03/02/2020

- Editora-associada: 1 (MSG)

- Revisores: 2

- Decisão editorial preliminar: 15/02/2020

- Retorno rodada de correções: 28/02/2020

- Decisão editorial final: 29/02/2020

\section{COMO CITAR ESTE ARTIGO:}

SANTORO, Antonio E. R. A imbricação entre maxiprocessos e colaboração premiada: o deslocamento do centro informativo para a fase investigatória na Operação Lava Jato. Revista Brasileira de Direito Processual Penal, Porto Alegre, vol. 6, n. 1, p. 81-116, jan./abr. 2020. https://doi.org/10.22197/rbdpp.v6i1.333

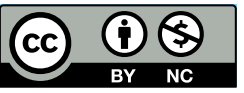

Esta obra está licenciada com uma Licença Creative Commons Atribuição-NãoComercial 4.0 Internacional. 